\title{
Sectoral Efficiency Level in Yogyakarta Province
}

\author{
Elkhana Fikriya', Fafurida ${ }^{\bowtie}$ \\ Jurusan Ekonomi Pembangunan, Fakultas Ekonomi, Universitas Negeri Semarang
}

Permalink/DOI: https://doi.org/10.15294/efficient.v2i1.30256

Received: July 2018 ; Accepted: October 2018 ; Published: Januari 2019

\begin{abstract}
The purpose of this study is to determine the level of efficiency, level of inefficiency and solutions that need to be done to improve the efficiency of each sector in the Yogyakarta Province. This research is a quantitative research with Data Envelopment Analysis (DEA) approach banxia frontier analysis. Variable used in this research is variable input (labor and investment), and output variable (GRDP). The data used are secondary data for the period $2012-2016$ from the Central Bureau Statistic. The research objects include main occupational sectors in Yogyalarta Province. The results of this study show that from nine sectors in DI Yogyakarta Province there are six sectors inefficient, namely the agricultural sector; mining and quarrying; processing industry; electricity, gas and water; Large trade; and other services during 2012 - 2016. Three of the nine sectors namely the construction sector; transport; and finance reached $100 \%$ efficiency during 2012 2016. Sectoral inefficiency occurs because the combination of the varabel quantity of the input is not appropriate, so it needs to be adjusted input factor quantity in order to produce the output efficiently $100 \%$. The conclusion of this study shows the efficiency of sectoral techniques in the Province of Yogyakarta in the tendency of low efficiency which decreases each year. Based on the results of the study the authors suggest six of the nine sectors that have not achieved 1oo\% efficiency rating need to adjust the amount of input factor value in order to achieve ouput efficiently $100 \%$
\end{abstract}

\section{Keywords: Sectoral, Efficiency, Data Envelopment Analysis}

\begin{abstract}
Abstrak
Tujuan penelitian ini adalah untuk mengetahui tingkat efisiensi, tingkat inefisiensi serta solusi yang perlu dilakukan untuk meningkatkan efisiensi tiap sektor di Provinsi DI Yogyakarta. Penelitian ini merupakan penelitian kuantitatif dengan metode Data Envelopment Analysis (DEA) pendekatan banxia frontier analysis.Variabel yang digunakan dalam penelitian ini adalah variabel input (tenaga kerja dan investasi), dan variabel output (PDRB). Data yang digunakan adalah data sekunder periode tahun 2012 - 2016. Dari Badan Pusat Statistik. Adapun objek penelitian meliputi sembilan sektor pekerjaan utama di Provinsi DI Yogyakarta. Hasil penelitian ini menunjukan bahwa dari sembilan sektor di Provinsi DI Yogyakarta terdapat enam sektor yang inefisien yakni sektor pertanian; pertambangan dan penggalian; industri pengolahan; listrik, gas, dan air; perdagangan besar; dan jasa lainnya selama tahun 2012 - 2016 . Tiga dari sembilan sektor yakni sektor konstruksi; angkutan; dan keuangan mencapai efisien 100\% selama tahun 2012 - 2016. Inefisiensi sektoral terjadi karena pengkombinasian besaran varabel input yang tidak sesuai, sehingga perlu dilakukan penyesuaian besaran faktor input dalam rangka menghasilkan output secara efisien $100 \%$. Kesimpulan dari penelitian ini menunjukkan efisiensi teknik sektoral di Provinsi DI Yogyakarta kecenderungan efisiensi rendah yang menurun tiap tahunnya. Berdasarkan hasil penelitian penulis menyarankan enam dari sembilan sektor yang belum mencapai nilai efisiensi $100 \%$ perlu melakukan penyesuaian besaran nilai faktor input dalam rangka mencapai ouput secara efisien $100 \%$.
\end{abstract}

\section{Kata Kunci: Sektoral, Efesiensi, Analisis Balutan Data}

How to Cite: Fikriya, E., \& Fafurida, F. (2019). Sectoral Efficiency Level in Yogyakarta Province. EFFICIENT Indonesian Journal of Development Economics, 2(1), 298-309. Retrieved from https://journal.unnes.ac.id/sju/index.php/efficient/article/view/30256

(C) 2019 Semarang State University. All rights reserved

\footnotetext{
Alamat Korespondensi :

Alamat: Gedung L2 Lantai 2 FE Unnes

Kampus Sekaran, Gunungpati, Semarang, 50229

E-mail : efficientjournal@gmail.com
} 


\section{INTRODUCTION}

Economic growth is one of the macroeconomic indicators which is most often used by a country, especially for developing countries. Indicators of economic growth are considered to be eligible for use even though they are not sufficiently able to explain well in knowing the economic conditions of a country (Prasetyo, 2009). One of the measurement of regional economic growth can be seen through the rate of economic growth or Gross Regional Domestic Product (GRDP). GRDP indicators can show economic activity in a certain period.
The implementation of regional autonomy policy is based on the Law of the Republic of Indonesia Number 23 of 2014 concerning the local government. The regional government is given the authority by the central government to regulate and manage its own regional government affairs. Regional economic development is basically to accelerate the realization of public welfare and equitable development where the participation of government and society is very important. Because regional inequalities can also weaken national economic growth ( Yozi A.R, et all, 2014)

Table 1. Growth Rate of GRDP of Java Island Province in $2012-2016$ on the basis of the 2010 Constant Price (\%)

\begin{tabular}{llllllll}
\hline Num . & Province & $\mathbf{2 0 1 2}$ & $\mathbf{2 0 1 3}$ & $\mathbf{2 0 1 4}$ & 2015 & 2016 & Average \\
\hline 1. & DKI Jakarta & 6,53 & 6,07 & 5,91 & 5,89 & 5,85 & 6,05 \\
2. & Jawa Barat & 6,5 & 6,33 & 5,09 & 5,04 & 5,67 & 5,73 \\
3. & Jawa Tengah & 5,34 & 5,11 & 5,27 & 5,47 & 5,28 & 5,29 \\
4. & DI Yogyakarta & 5,37 & 5,47 & 5,17 & 4,95 & 5,05 & 5,20 \\
5. & Jawa Timur & 6,64 & 6,08 & 5,68 & 5,44 & 5,55 & 5,91 \\
6. & Banten & 6,83 & 6,67 & 5,51 & 5,4 & 5,26 & 5,93
\end{tabular}

Source: Central Bureau of Statistics (2017)

Java is the heart or center of economic activity and government in Indonesia. According to a report from the Central Statistics Agency (2017), the island of Java provided a substantial contribution of $58,49 \%$ to Indonesia's national income. The economies of the provinces in Java are quite developed. However, DI Yogyakarta Province is the region that has the lowest GRDP growth rate among other provinces. Table 1 is the growth rate of GRDP of the Java Island Province sourced from the Central Bureau of Statistics. Based on Table 1, it shows that the GRDP growth rate of DI Yogyakarta Province was the lowest during
2015 and 2016, which was 4,09\% and 5,05\%. The average GRDP growth rate of DI Yogyakarta Province from 2012 to 2016 also showed the lowest that is $5,20 \%$.

The ability of the local government to analyze the potential of regional natural resources is a challenge for the local government in maximizing revenue to finance the governance and development processes. Management of natural resources to maximize revenue in order to run government one of them is to see the potential of each sector in the region. The economic sector is one of the contributions to regional income or GRDP. 
Percentage distribution of GRDP in Yogyakarta Province according to the business field in 2012-2016 in the figure 1.

Based on Figure 1, it shows that the development of the percentage distribution of GRDP according to the business field in 2012 to 2016. The sector that contributed the most to the GRDP of the DI Yogyakarta Province was the manufacturing industry sector, followed by the information and communication sector, and the construction sector. While the sectors that provide the least contribution are the water supply sector, electricity and gas procurement sector, and the mining sector. The ability of an economic sector to produce goods and services will increase along with the large growth of production factors experiencing an increase in the number and quality. The resources used in the production process based on the Cobb-Douglas production function are labor and capital.

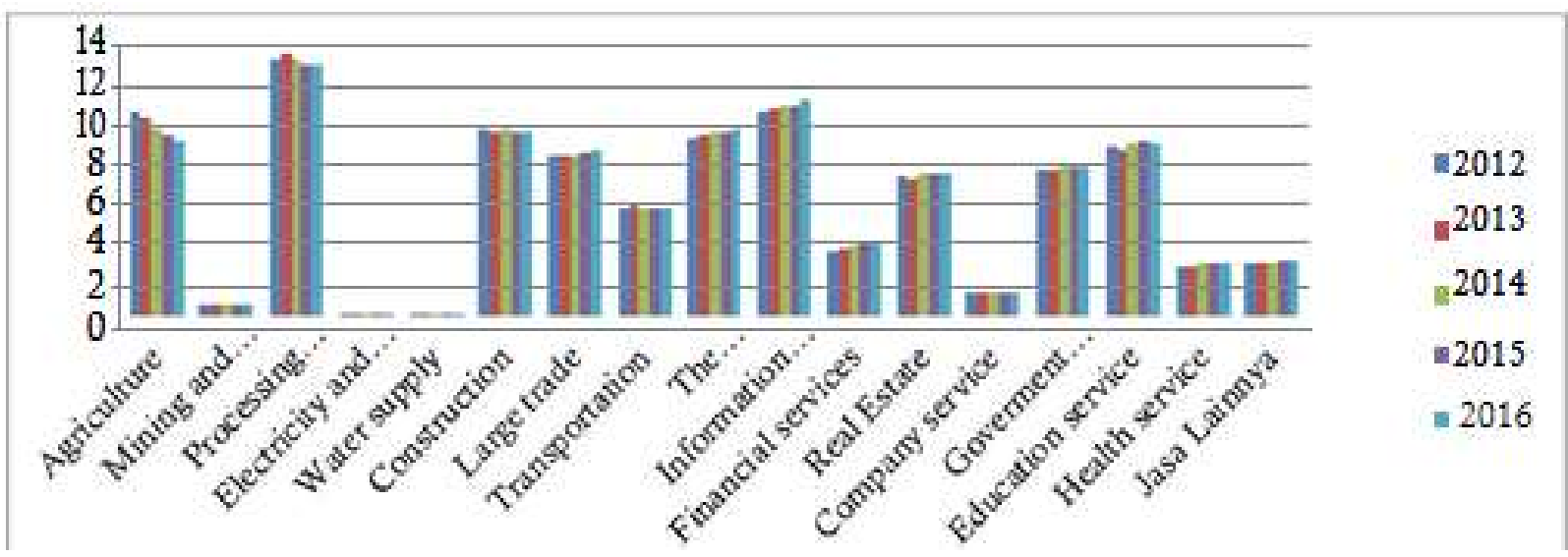

Figure 1. Percentage Distribution of DI Yogyakarta Province Gross Regional Domestic Product 2010 ADHK According to Business Fields 2012-2016 (\%)

Source: Yogyakarta Provincial Statistics Agency (2017)

Labor is used as a factor of production to production. The following is data on labor produce goods and services. A greater amount according to the main jobs in DI Yogyakarta of labor means increasing the level of Province in 2012-2016:

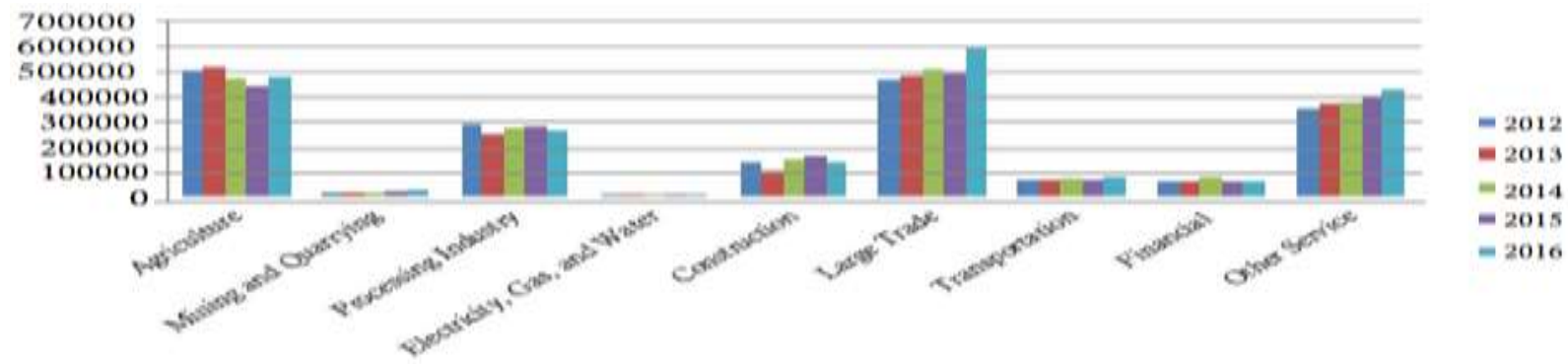

Figure 2. Labor in the Yogyakarta Province ADHK 2010 According to the 2012 -2016 Main Employment Field (People)

Source: Yogyakarta Provincial Statistics Agency (2017) 
Figure 2 is the data og labor in the Yogyakarta Province according to the main jobs in 2012 to 2016. Based on figure 2, it show that the number of workers in each sector experienced growth. The sector that absord the most labor is in the large trade sector and the agricultural sector. This is not in accordance with the persentage distribution of GRDP in the DI Yogyakarta Province as shown in figure 1 which shows that the sector that provides the largest contribution is in the manufacturing industry and the information and communication sector.

Investment are made to form factors of production in the form of capital, where a portion of the investment is used to procure various types of capital goods that willbe used in the production process. The investment in each economics sector is expected to increase productivity so that goods and services will increase. The following are investment data according to business fields in DI Yogyakarta province in $2012 \quad-\quad 2016$.

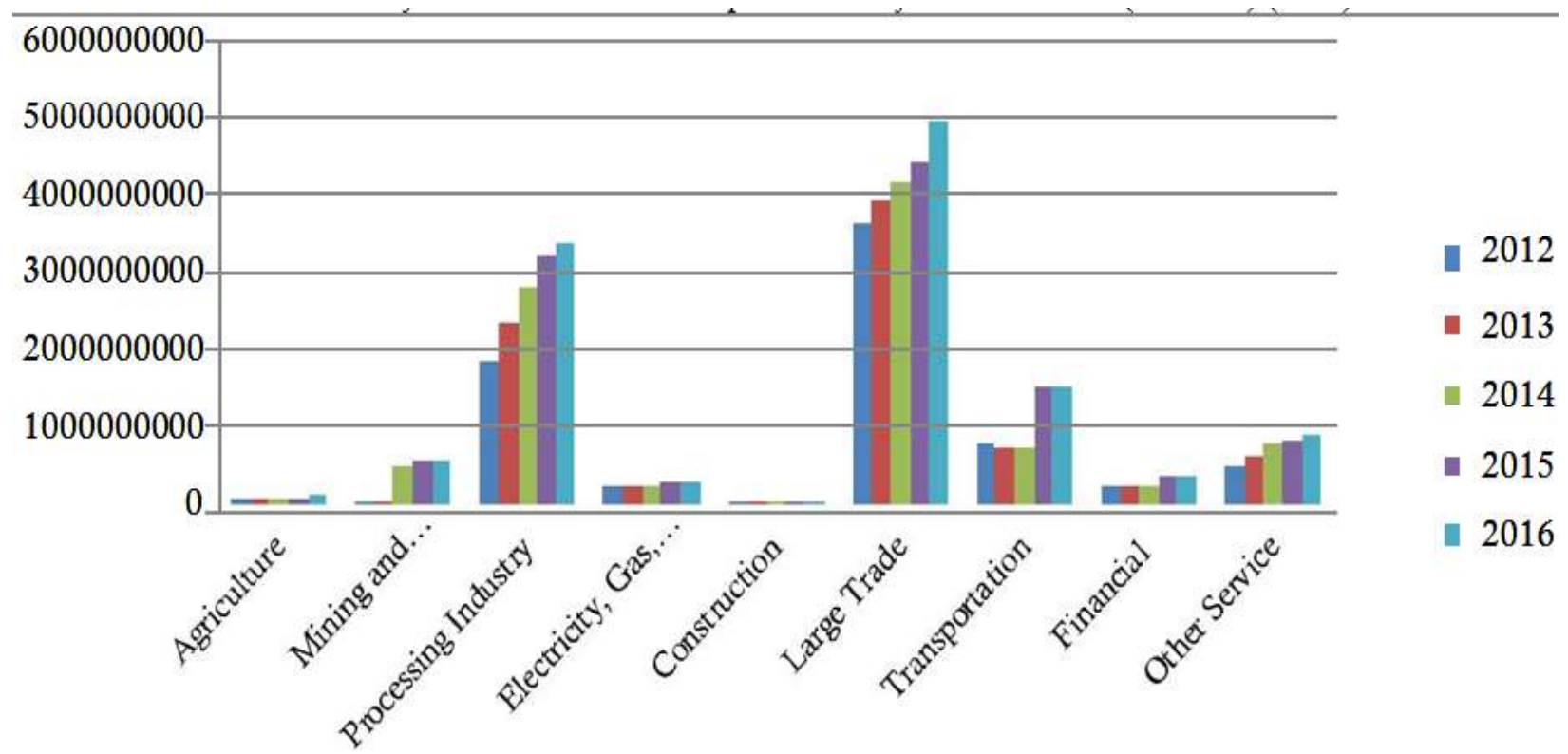

Figure 3. Investment in DI Yogyakarta Province ADHK 2010 According to Main Business Fields 2012-2016 (Million Rupiah)

Source: Yogyakarta Provincial Statistics Agency (2017)

Figure 3 is the investment data in the processing industry sector is in DI Yogyakarta Province according to the accordance with the percentage distribution main business field in 2012 to 2016. Based on of GRDP in Yogyakarta Province figure 3, it shows that almost each which is found in Figure 2 that the sector experienced an increase in the manufacturing industry sector is the amount of investment from 2012- 2016. largest contributor to GRDP. However, it The most amount of investment is in is different from the trade sector which the large trade and processing industries. occupies the sixth position as a contributor The large amount of investment in to GDP in the Province of DI Yogayakarta. 
The most significant contribution of the contributing sector between labor, investment, and the percentage distribution of GDP in the economic sector in DI Yogyakarta Province indicates that the lack of optimal input factors in the form of labor and investment in producing the output is GRDP. Increased goods and services of each sector can be occured if the factors of production input in the form of labor and investment are able to optimally produce output or called efficiency. The ability to produce output optimally with existing input is one of the results of good performance. Economic sector efficiency analysis is carried out to find out more about how the right combination of input and output factors in an efficient economic sector performance.

According to Ikram (2012) in his research it was stated that knowledge of any sector in an efficient area is important to be studied. It is necessary to know which sectors in the region show the best development so far. Conversely, sectors with low efficiency levels need regional economic policy support to develop the sector. Awirya (2011) in his research said that researches on the leading sectors were mostly done to focus the allocation of funds and the direction of economic development. Seeing the importance of the role of each economic sector in the GRDPn contribution in Yogyakarta Province, it is necessary to have an in -depth analysis of the level of efficiency of each economic sector. Efficiency analysis is based on a relatively technical efficiency approach to determine the relationship of input-output ratios in the production process carried out by each economic sector.

\section{RESEARCH METHOD}

This research is quantitative research. The type of data used in this study is secondary data. The data used in this study is data on labor, investment, and GRDP of each sector in DI Yogyakarta Province through data collection documentation at the Yogyakarta Central Statistics Agency. Data collection method used in this research is literature study. The subject of this study are the nine main sectors of the economy of DI Yogyakarta Province. The nine sectors are the agricultural sector; mining and quarrying sector; processing industry sector; electricity, gas and water sector; construction sector; large trade sector; transportation sector; financial sector; and other service sectors.

According to the specified object, the input and output variables will be explored which will be the material to determine the level of sectoral efficiency in the Yogyakarta Province. Identification of inputoutput variables used in measuring efficiency levels is the first and most important step (Prasetyo D. 2010). The input and output variables used in this study are: Total Manpower (I1), Invesment (I2), GRDP (O1). As a guideline, the relationship between input and output variables must be based on exclusivity and exhaustiveness which means that only the input variables can affect the output variables and only the output variables used in the measurement can be influenced (Prajanti 2013). But the terms can be softened by assuming that the variables outside the measurement variable will not damage the proportionality value of the input and output variables used. 
The measurement of the efficiency level of the economic sector in DI Yogyakarta Province in this study uses a Data Envelopment Analysis (DEA) analysis tool with basic references of input and output variables, which are analyzed with the help of Banxia Frontier Analysis 4.o (BFA) application. Data Envelopment Analysis (DEA) method is a nonparametric method based on linear programming. DEA measures the relative efficiency ratio of the Economic Activity Unit (UKE) as the weighted output ratio with weighted inputs. Conceptually,

DEA describes the steps designed to measure the relative efficiency of a particular economic unit with several other economic units in one observation, where they use the same type of input and output. The application of the DEA method is assumed to overcome the limitations of multiple regression or partial ratio analysis. In the discussion of DEA, producers often interpreted it as a decision making unit (DMU). DEA shows an economic unit that has perfect efficiency with a value of $100 \%$ and a less efficient one with a value of $<100 \%$. Besides, there are multiplier numbers that are used as a basis for managerial improvement.

In order to ensure the level of efficiency achievement in the economic sector in a sectoral and overall manner, it is necessary to divide the criteria of efficiency level measurement, namely high efficiency, moderate efficiency, low efficiency, and inefficient. The efficiency level criteria can be seen in table 2 below:

Table 2. Sectoral Level Efficiency Size Criteria in DI Yogyakarta Province

\begin{tabular}{cc}
\hline Efficiency Criteria & Value of Efficiency \\
\hline Perfect/Optimum & 1 \\
High & $0,81-0,99$ or $\leq 0,81 \leq 0,99$ \\
Medium & $0,60-0,8$ o or $\leq 0,60 \leq 0,80$ \\
Low & $0,41-0,59$ or $\leq 0,41 \leq 0,59$ \\
Not Efficient & $\leq 0,40$ \\
\hline
\end{tabular}

Sumber: Fathoni, 2016

The ratio between input and output is as follows (Kormayatin, 2006):

$$
H s=\frac{\sum_{t=1}^{m} U i . Y i s}{\sum_{j=i}^{n} V j . X j S}
$$

Where:

$$
\begin{aligned}
\mathrm{Hs}= & \text { efficiency per business sector } \\
\mathrm{m}= & \text { observed sectoral output } \\
\mathrm{n}= & \text { observed sectoral input } \\
\mathrm{yis}= & \text { the amount of output } \mathrm{i} \text { that will } \\
& \quad \text { be used per business sector }
\end{aligned}
$$

$$
\begin{aligned}
\text { xis }= & \text { the amount of input } j \text { used by } \\
& \text { the business sector } \\
\text { ui }= & \begin{array}{l}
\text { output weight } \mathrm{i} \text { produces per } \\
\text { sector of business sector }
\end{array} \\
\mathrm{Vj}= & \begin{array}{l}
\text { input weight } \mathrm{j} \text { given per business } \\
\text { sector }
\end{array}
\end{aligned}
$$

The efficiency ratio (hs) above is then maximized with the following constraints:

$H s=\frac{\sum_{t=1}^{m} U i . Y i r}{\sum_{j=1}^{n} V j . X j r}<1$ 
A DMU or a business field sector is said to be efficient or not if the TE value in each DMU ranges from 0 to 1 or 0 to $100 \%$. A DMU has the best ability if the relative efficiency value is 1 or $100 \%$ while other DMUs whose values are below $100 \%$ are said to be still below the DMU that has been inefficient.

\section{RESULTS AND DISCUSSION}

Sectoral efficiency is one of the indicators in measuring the performance of each economic sector in the Yogyakarta Province. The performance of each sector is said to be perfect / optimum efficiency if the efficiency ratio of input and output factors is equal to 1 or $(100 \%)$, while if the efficiency value approaches $\leq 0,40$ it is said to be inefficient, if the efficiency value is $0,41 \quad-0,59$ then the efficiency is low, if the efficiency value is $0,60-0,80$ then the efficiency is moderate, and if the efficiency value is $0,81-0,99$ then the efficiency is high.

Table 3. Results of Calculation of Sectoral Technical Efficiency Levels in Yogyakarta Province in 2012-2016

\begin{tabular}{cccccccc}
\hline Num & Sectoral & \multicolumn{7}{c}{ Efficiency Value Ratio } & Average \\
\hline & & 2012 & 2013 & 2014 & 2015 & 2016 & \\
1. & Agriculture & 0,3817 & 0,2743 & 0,5359 & 0,4137 & 0,3607 & 0,3933 \\
2. & Mining and Quarrying & 1 & 1 & 0,1809 & 0,1365 & 0,1168 & 0,4868 \\
3. & Processing Industry & 0,2113 & 0,2223 & 0,2079 & 0,2025 & 0,2264 & 0,2141 \\
4. & Electricity, Gas, and Water & 0,3717 & 0,1990 & 0,3808 & 0,3819 & 0,2805 & 0,3228 \\
5. & Construction & 1 & 1 & 1 & 1 & 1 & 1 \\
6. & Large Trade & 0,1618 & 0,1536 & 0,1629 & 0,1643 & 0,1411 & 0,1567 \\
7. & Transportation & 1 & 1 & 1 & 1 & 1 & 1 \\
8. & Financial & 1 & 1 & 1 & 1 & 1 & 1 \\
9. & Other Service & 0,5349 & 0,4242 & 0,4427 & 0,5032 & 0,4592 & 0,4728 \\
\hline
\end{tabular}

Source: Data Processed 2018.

There are nine economic sectors observed in 2012 - 2016. There are three sectors that always achieve perfect or optimum technical efficiency equal to 1 or $100 \%$ in 2012 2016, the sectors are the construction sector, transportation sector, and financial sector. There are six sectors that get inefficiencies or have not been able to achieve 100\% efficiency, namely the agricultural sector; mining and quarrying sector; processing industry sector; electricity, gas and water sector; large trade sector, and other service sectors.

The agricultural sector got inefficiency from 2012 - 2016, with the lowest efficiency achievement of 0.2743 (2013) less than 0.40 which means it is not efficient in running its business. The mining sector got efficiency in 2012 - 2013, while in 2014 - 2016 experienced inefficiencies. The value of the efficiency of the mining sector continues to decline starting in 
2014 at $0,1809 \leq 0,40$ meaning it is inefficient, amounting to $0,1365 \leq 0,40$ means that it is inefficient (2015), and $0,1165 \leq 0,40$ means it is inefficient (2016) The processing industry sector got inefficiencies from 2012 - 2016, with the lowest efficiency achievement value of $0,2079(2015) \leq 0,40$ meaning that it is not efficient in running its business.

The electricity, gas and water sectors got inefficiencies from 2012 - 2016, with the lowest efficiency achievement value of 0,1990 (2013) $\leq 0,40$ meaning that they were not efficient in running their business. The large mtrade sector got inefficiencies from 2012 2016, with the lowest efficiency achievement of $0,1411(2016) \leq 0,40$ which means that it is not efficient in running its business. Other service sectors got inefficiencies from $2012-2016$, with the lowest efficiency achievement of $0,4242(2013) \leq 0,41-\leq 0,59$ which means low efficiency in running their business. Sectors that have not yet achieved 100\% technical efficiency are advised to adjust the combination of the value of input factors in order to produce input factors efficiently.

According to table 4 in the appendix, we can see that the highest level of efficiency in the economic sector in the DI Province of Yogyakarta is in 2012 - 2013 with an efficiency level of $44 \%$ (nine economic sectors) $\leq 41 \%-\leq 59 \%$ which means low efficiency. While the highest average efficiency level occurred in 2012, with an average efficiency rate of $63 \%$ (nine economic sectors) $\leq 60 \%-\leq 80 \%$, which means moderate efficiency. In addition, the highest level of inefficiency occurred in 2014-2016, which amounted to $67 \%$ (six economic sectors) $60 \%-\leq 80 \%$ which means medium efficiency.
This is in line with the research conducted by Adila (2014) on "Sectoral Efficiency Analysis in Central Java Province by Using Data Envelopment Analysis (DEA) 20002012", it is stated that there needs to be an adjustment to input factors, for sectors that have not been able to achieve optimum / perfect $100 \%$ technical efficiency level. Adjustment of the magnitude of input factors is done in order to increase the efficiency value of economic sectors in Yogyakarta Province which has not been able to achieve optimum / perfect $100 \%$ efficiency.

Some of the causes of economic sector inefficiency are the incompatibility of the combination of the magnitude of inputs and outputs in the economic sector, in this case we can see through the results of technical analysis of the economic sector. Inefficiency of the economic sector shows a discrepancy between the target and realization. According to Setiawan and Bowo (2015) in his research entitled "Technical Efficiency, Allocative, and Rice Cultivation Economy", explained that the incompatibility between targets and realization is a phenomenon that must be studied and resolved. Therefore, it is necessary to know the causes of inefficiencies and solutions to improvements towards efficiency.

One of the causes of economic sector inefficiency is the use of a combination of the amount of labor as an inappropriate input factor. The results of this study are supported by Masru'ah (2012) research stating that the inequality of research results with theory can be due to the effect of the law of diminishing return, the addition of labor in the agricultural sector is no longer able to increase the GRDP of the agricultural sector or effect of the law of diminishing return. 
Besides, the cause of economic sector inefficiency is the use of a combination of the amount of investment amount as an inappropriate input factor. The results of this study are in accordance with Mutiara's (2016) study that the addition of investment does not show an increase in output in the mining and quarrying sector because the potential of the mining and quarrying sector is limited and less potential so that the additional investment in this sector will be less effective and efficient.

According to Susilo (2007), it seems unlikely that we will reduce the available resources, instead we must optimize the acquisition of the economic sector output, for example we are not possible to reduce the level of education, capital, and others. The solution that can be suggested is by monitoring investments by local governments and related parties. This monitoring is a kind of selfevaluation, so that not only investments are monitored but all operational activities. Selfevaluation must be followed up for example by providing additional capital, guidance, adding infrastructure, human resources, and institutions.

\section{CONCLUSION}

Sectoral engineering efficiency analysis in DI Yogyakarta Province in 2012-2016 shows the results of the tendency of low efficiency which decreases each year. During 2012 - 2016 there were three of the nine economic sectors in the Yogyakarta Province that were able to achieve $100 \%$ optimum / optimum efficiency. Meanwhile, there are six of the nine economic sectors in the Yogyakarta Province that have not been able to achieve $100 \%$ optimum / optimum efficiency in 2012 - 2016. During 2012
- 2016 from the nine economic sectors, there were three sectors that were categorized as $100 \%$ optimum / optimum efficiency. The sectors are the construction sector, the transport sector and the financial sector. While the other six sectors are agriculture; mining and quarrying sector; processing industry sector; electricity, gas and water sector; large trade sector; and other service sectors during 2012 - 2016 have not reached 100\% efficiency level.

Sectoral inefficiency occurs due to a combination of the amount of input factors in the form of labor and investment that are not yet appropriate in an effort to produce a certain level of output. The solution in increasing the level of sectoral efficiency that has not reached $100 \%$, it is necessary to adjust the amount of input value and the magnitude of the output value to be more appropriate. So that, it is able to achieve $100 \%$ optimum / optimum efficiency. Alternative solution is to reduce the amount of combination of input value in the form of labor and investment or increase the magnitude of the combination of output value in the form of GDP according to potential improvement in each sectoral fan output input factor that has not reached 100\% optimum / optimum efficiency, namely the agricultural sector; mining; processing industry; electricity, gas and water; Large trade; and other services.

\section{REFERENCES}
Adila, N. (2014). Analisis Efisiensi Sektoral Provinsi Jawa tengah dengan Menggunakan Data Envelopment Analysis (DEA) Periode 2000-2012 (Doctoral dissertation, Universitas Muhammadiyah Surakarta).


Al-Delaimi, Khalid, Shahooth. (2006). Using Data Envelopment Analysis to Measure Cost Efisiency With an Aplication on Islamic Bank. Scientific. Journal of Administrative Development. Vol. 41.

Anggraini, E. D., \& Soebagyo, D. (2017). Analisis Tingkat Efisiensi Sektoral di Jawa Tengah Menggunakan Data Envelopment Analysis (DEA) Periode 20052014. (Doctoral dissertation, Universitas Muhammadiyah Surakarta).

Assauri, Sofjan (2004). Manajemen Produksi dan Operasi. Lembaga Penerbit Fakultas Ekonomi Universitas Indonesia.

Awirya, A. A. (2011). Pengembangan Sektor Utama Regional Pendekatan Efisiensi Teknikal Dan Siklus Bisnis Studi Kasus di Provinsi Bali. JEJAK: Jurnal Ekonomi dan Kebijakan, 4 (1).

Badan Pusat Statistik. (2016). Analisis Makro Ekonomi Daerah Istimewa Yogyakarta. Yogyakarta: Badan Perencanaan Pembangunan Daerah.

Badan Pusat Statistik. (2017). Laju Pertumbuhan PDRB Provinsi Jawa Tengah Tahun 2012-2016 Atas Dasar Harga Konstan 2010. Statistika Indonesia

Badan Pusat Statistik Provinsi Yogyakarta. (2016). Analisis Informasi Statistik Pembangunan Daerah Istimewa Yogyakarta 2016. Yogyakarta: Badan Perencanaan Pembangunan Daerah - BPS Daerah Istimewa Yogyakarta.

Badan Pusat Statistik Provinsi Yogyakarta. (2017). Analisis ICOR Sektoral Daerah Istimewa Yogyakarta 20122016. Yogyakarta: Badan Perencanaan Pembangunan Daerah.

Badan Pusat Statistik Provinsi Yogyakarta. (2017). Analisis Produk Domestik Regional Bruto Daerah Istimewa Yogyakarta 2012-2016. Yogyakarta: Badan Pusat Statistik Provinsi D.I Yogyakarta.

Badan Pusat Statistik Provinsi Yogyakarta. (2017). Produk Domestik Regional Bruto Provinsi Daerah Istimewa Yogyakarta Menurut Lapangan Usaha Tahun 2012-2016. Yogyakarta: BPS DI Yogyakarta.

Case, K. E., \& Ray, C. F. (2006). Prinsip-Prinsip Ekonomi, Edisi Kedelapan. Jilid 1. Jakarta: Erlangga

Coelli, T. (1996). A guide to DEAP Version 2.1: a data envelopment analysis (computer) program. Centre for Efficiency and Productivity Analysis, University of New England, Australia.

Fathoni, As'ad Asyhar. (2016). Analisis Efisiensi Ekonomi Industri Tekstil dan Produk Tekstil Provinsi Jawa Tengah. EDAJ: Economics Development Analysis Journal, 5 (1). 74-83.
Ikram, M. A. M., Prasmuko, A, Anugerah, D. F., \& Kurniati, I. N. (2012). Analisis Tingkat Efisiensi Sektoral Dan Kebijakan Ekonomi Sektoral Di Daerah. Bulletin of Monetary Economics and Banking , 14 (3), 317-338.

Kajian Ekonomi Regional Provinsi Kalimantan Tengah (Ed). (2010). Efisiensi Sektoral Di Kalimantan Tengah (Periode 2004-2008). Kajian Ekonomi Regional Provinsi Kalimantan Tengah Triwulan IV, 1-4.

Mankiw, G. N. (2014). Pengantar Ekonomi Mikro Edisi Asia . Jakarta: Salemba Empat.

Masru'ah, Dewi., Soejoto, Ady. (2012). Pengaruh Tenaga Kerja dan Investasi di Sektor Pertanian Terhadap Pertumbuhan Sektor Pertanian di Provinsi Jawa Timur. Jurnal Pendidikan Ekonomi, Manajemen, dan Keuangan. Fakultas Ekonomi, Universitas Negeri Surabaya.

Muchdie. (2016, Oktober). Sectoral Variations On Technical Efficiency and Return To Scale in The Indonesian Economy. Jurnal Ilmu Ekonomi, 5 (2), 119-132.

Mutiara, C. C., \& Bendesa, I, Komang, Gde. (2016) Penyerapan Tenaga Kerja Sektoral Menurut Sifat Produksi Sektor Ekonomi di Bali. E-Jurnal Ekonomi dan Bisnis Universitas Udayana . 5.6:1595-1620.

Nugroho, A. D., Waluyati, L. R. (2018). Upaya Memikat Generasi Muda Bekerja pada Sektor Pertanian di Daerah Istimewa Yogyakarta. JPPUMA: Jurnal Ilmu Pemerintahan dan Sosial Politik UMA. 6 (1): 78-95.

Pamungkas , B. D., Kurniawansyah, \& Mustaram, R. A. (2017). Analisis Pengaruh Investasi dan Tenaga Kerja Terhadap PDRB Kabupaten Sumbawa Tahun 2010-2016. Jurnal Ekonomi dan Bisnis, 213228.

Prajanti, S. D. (2013a). Metode Analisis Efisiensi Produksi dan Pengambilan Keputusan pada Bidang Ekonomi Pertanian. Semarang:

Unnes Press.

Prasetyo, P. E. (2009). Fundamental Makro Ekonomi. Yogyakarta: Beta Offset.

-. P. Eko. (2017). Productivity of Textile Industry and Textile Products in Central Java. JEJAK (Jurnal Ekonomi dan Kebijakan). Vol. 10 (2). 257-272.

Prasetyo, Danang. (2010). Analisis Efisiensi Teknik dan Alokatif Hotel di Kawasan Wisata Tawangmangu Kabupaten Karanganyar dengan Menggunakan 
Metode Data Envelopment Analysis. Skripsi. Fakultas Ekonomi: Universitas Sebelas Maret.

Rubedo, Hendar. (2011). Pengaruh Bauran Pemasaran Jasa Terhadap Loyalitas Konsumen (Survey pada Mahasiswa Strata 1 Semester VIII pada Universitas Komputer Indonesia) . Skripsi. Universitas Negeri Komputer Indonesia.

Setiawan, A. B., \& Prajanti, S. D. (2011). Analisis Efisiensi Penggunaan Faktor-Faktor Produksi Usaha Tani Jagung di Kabupaten Grobogan Tahun 2008. JEJAK (Jurnal Ekonomi dan Kebijakan). 69-76.

Setiawan, A. B., \& Bowo, Prasetyo, A. (2015). Efisiensi Teknis, Alokatif, dan Ekonomi Budidaya Padi. JEJAK (Jurnal Ekonomi dan Kebijakan). Vol. 2 (2). 1-8.

Soekarwati. (1993). Prinsip Dasar Ekonomi Teori dan Aplikasi. Jakarta: PT. Raja Grafindo.

Sugiarto, dkk. (2002). Ekonomi Mikro Sebuah Kajian Komprehensif. Jakarta: Gramedia Pustaka Utama.

Sugiyono. (2015). Metode Penelitian Kuantitatif, Kualitatif, dan R\&D. Bandung: AFABETA.

Sukirno, S. (2013). Ekonomi Pembangunan: Proses, Masalah, dan Dasar Kebijakan (Edisi Kedua). Jakarta: Kencana Prenadamedia Group.

Susila, Ihwan. (2007). Analisis Efisiensi Lembaga Keuangan Mikro. Jurnal Ekonomi Pembangunan, Vol. 8 (2). 223-242.

Sutanto, H. A., \& Imaningati, S. (2014). Tingkat Efisiensi Produksi Dan Pendapatan Pada Usaha
Pengolahan Ikan Asin Skala Kecil. JEJAK: Jurnal Ekonomi dan Kebijakan, 7 (1). 73-84.

Sutawijaya, Adrian, \& Lestari, Etty Puji. (2009). Efisiensi Teknik Perbankan Indonesia Pascakrisis Ekonomi: Sebuah Studi Empiris Penerapan Model DEA. Jurnal Ekonomi Pembangunan, Vol. 10 (1). 49-67.

Tarigan, R. (2005). Ekonomi Regional: Teori dan Aplikasi. Jakarta: Bumi Aksara.

Tim Penyusun Kamus Pusat Bahasa . (2008). Kamus Besar Bahasa Indonesia . Jakarta : Pusat Bahasa Departemen Pendidikan Nasional.

Todaro, M. P. (200o). Pembangunan Ekonomi di Dunia Ketiga. Jakarta: Erlangga.

Undang-Undang Republik Indonesia Nomor 25 Tahun 2004 Tentang Sistem Perencanaan Pembangunan Nasional. (2004). Jakarta: Presiden Republik Indonesia.

Wulansari, Retno. 2010. Efisiensi Relatif Operasional Puskesmas dengan menggunakan Data Envelopment Analysis (DEA). Jurnal Ekonomi Universitas Indonesia. 1-14.

Rahman, Yozi A., dkk. (2014). Fiscal Decentralization and Economic Growth : Case of Indonesia. Conference: The 12th IRSA International Conference:Political Economy of Regional Development in Indonesia, At Makasar. https://www.researchgate.net/publication/318284 748_Fiscal_Decentralization_and_Economic_Gro wth_Case_of_Indonesia. 


\section{APPENDIX}

Table 4. Efficiency Level, Average Efficiency of Each General Sector

\begin{tabular}{|c|c|c|c|c|c|}
\hline Information & 2012 & 2013 & 2014 & 2015 & 2016 \\
\hline \multicolumn{6}{|l|}{ Number of } \\
\hline $\begin{array}{l}\text { Efficient } \\
\text { Sectors }\end{array}$ & 4 & 4 & 3 & 3 & 3 \\
\hline Number of & & & & & \\
\hline $\begin{array}{l}\text { Inefficient } \\
\text { Sectors }\end{array}$ & 5 & 5 & 6 & 6 & 6 \\
\hline \% Efficient & & & & & \\
\hline $\begin{array}{l}\text { Sector } \\
\% \text { Inefficient }\end{array}$ & $44 \%$ & $44 \%$ & $33 \%$ & $33 \%$ & $33 \%$ \\
\hline Sector & $56 \%$ & $56 \%$ & $67 \%$ & $67 \%$ & $67 \%$ \\
\hline
\end{tabular}

Sector

- Mining and - Mining and - Construction - Construction - Construction Quarrying Quarrying - Transportati- - Transportati- - Transportati-

Efficient - Construction - Construction on on

Sectors - Transportati- - Transportati- - Financial - Financial - Financial on on

- Financial - Financial

- Agriculture - Agriculture - Agriculture - Agriculture - Agriculture

- Processing - Processing - Mining and - Mining and - Mining and

Industry Industry Quarrying Quarrying Quarrying

- Electricity, - Electricity, - Processing - Processing - Processing

Inefficient Gas, and water Gas, and Industry Industry Industry

Sectors Water - Electricity, - Electricity, - Electricity,

- Large Trade - Large Trade Gas, and Gas, and Gas, and

- Other Service - Other Service Water Water Water

- Large Trade - Large Trade - Large Trade

Other

- Other Service - Other Service Service

$\begin{array}{llllll}\text { Average } & 63 \% & 59 \% & 55 \% & 53 \% & 51 \%\end{array}$

Source: Data Processed 2018 